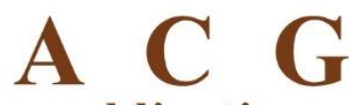

publications

Org. Commun. 11:4 (2018) 173-180

organic

communications

\title{
Synthesis and optical properties of some isoindole-1,3-dione compounds: Optical band gap, refractive index and absorbance band edge
}

\author{
Ayse Tan $\odot^{1 *}$, Serap Kizilkaya $\odot^{2}$, Bayram Gunduz $\odot^{3}$ and Yunus Kara $\odot^{4}$ \\ ${ }^{I}$ Vocational School of Technical Sciences, Mus Alparslan University, 49250 Mus, Türkiye \\ ${ }^{2}$ Department of Chemistry, Faculty of Arts and Sciences, Mus Alparslan University, 49250 Mus, Türkiye \\ ${ }^{3}$ Department of Science Education, Faculty of Education, Mus Alparslan University, 49250 Mus, \\ Türkiye \\ ${ }^{4}$ Department of Chemistry, Faculty of Sciences, Ataturk University, 25240 Erzurum, Türkiye
}

(Received October 14, 2018; Revised November 23, 2018 ; Accepted November 26, 2018)

\begin{abstract}
Some isoindole-1,3-dione compounds (5, 6, 7, 8, 9, and 10) have been synthesized starting from 3a,4,7,7atetrahydroisobenzofuran-1,3-dione (4). Compounds $\mathbf{5}, \mathbf{6}, \mathbf{7}, \mathbf{8}, \mathbf{9}$, and 10 were characterized by ${ }^{1} \mathrm{H}$ and ${ }^{13} \mathrm{C} \mathrm{NMR}$ spectra, FT-IR spectroscopy, and mass spectra measurements. The optical properties of the isoindole-1,3-dione compounds $(\mathbf{5}, \mathbf{6}, \mathbf{7}, \mathbf{8}, \mathbf{9}$, and 10$)$ were also investigated. For this purpose, UV-Vis spectra of these compounds were recorded in $\mathrm{CH}_{2} \mathrm{Cl}_{2}$. The absorbance $(A b s)$, transmittance $(T)$, absorbance band edge $\left(E_{A b s-b e}\right)$, optical band gap $(E g)$, and refractive index $(n)$ of these compounds were calculated and application areas of these materials were sought.
\end{abstract}

Keywords: Isoindole-1,3-dione; optical parameters; refractive index; dielectric materials; insulator/dielectric behavior. (C2018 ACG Publication. All right reserved.

\section{Introduction}

Norcantharimide (1), phthalimide (2), $N$-substituted norcantharimide (3) are some examples of isoindole derivatives containing imide (-CO-N(R)-CO-) functional group (Figure 1). These compounds and their $\mathrm{N}$-substituted derivatives are interesting compounds due to their important biological properties in the field of synthetic organic chemistry, and medicinal chemistry. ${ }^{1,2}$ For this reason, many approaches have been developed for their efficient and versatile synthesis.

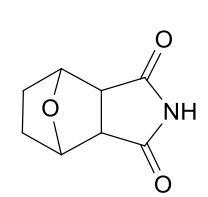

1<smiles>O=C1NC(=O)c2ccccc21</smiles>

2

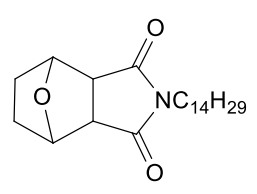

3

Figure 1. The structure of norcantharimide (1), phthalimide (2), and $\mathrm{N}$-substituted norcantharimide (3)

*Corresponding author: E-Mail: $\underline{\text { a.tan@alparslan.edu.tr }}$ 
Isoindole and its $N$-substituted derivatives have received attention due to their antibacterial, ${ }^{2}$ antifungal, ${ }^{2}$ analgesic, ${ }^{2}$ anti-HIV-1, ${ }^{2}$ anxiolytic, ${ }^{2,3}$ anti-inflammatory, ${ }^{4}$ anticonvulsant, ${ }^{5}$ antitumor ${ }^{2,6,7,8,9}$ and antimicrobial activities. ${ }^{10,11}$ Recently, we have reported the synthesis of some isoindole derivatives and their anticancer properties. ${ }^{12,13}$

Organic compounds with high nonlinear optical (NLO) properties have been used in the areas of telecommunication, high optical disk data storage, and optical information processing. ${ }^{14,15,16,17}$ NLO organic molecules possess delocalized $\pi$-electrons moving through the molecular system. ${ }^{14}$ Isoindoles (isoindoline-1,3-dione, isoindole-1,3-dione, and their $N$-substituted derivatives having a "-CO-N(R)-CO" structure) are considered as eligible candidates for NLO materials because of the delocalized $\pi$-electrons. Recently, the structural, spectroscopic, and electronic properties of some $N$-substituted isoindoline-1,3dione derivatives have been examined by both experimental and density functional theory methods. ${ }^{14,18,19,20}$ But the optical properties of isoindole-1,3-dione and their $N$-substituted derivatives have not been studied much.

In this study, we have reported the synthesis of novel $N$-substituted isoindole-1,3-dione derivatives $(\mathbf{7}, \mathbf{9}$, and $\mathbf{1 0})$ and investigated the optical properties of compounds $\mathbf{5}, \mathbf{6}, \mathbf{7}, \mathbf{8}, \mathbf{9}$, and $\mathbf{1 0}$. We compared their optical parameters with each other. We also sought application areas for these materials.

\section{Experimental}

All reagents and solvents were purchased from Sigma and Aldrich without further purification. The ${ }^{1} \mathrm{H}$ NMR and ${ }^{13} \mathrm{C}$ NMR spectra were recorded on a Varian $400 \mathrm{MHz}$ and a Bruker $400 \mathrm{MHz}$ spectrometer. Chemical shifts were given in parts per million (ppm). Abbreviations used to define multiplicities are as follows: $s=\operatorname{singlet;} d=$ doublet; $t=$ triplet; $q=$ quartet; $m=$ multiplet. The FT-IR spectrum was recorded with a Perkin Elmer spectrophotometer using an ATR head in the range of 4000$600 \mathrm{~cm}^{-1}$. M.p. was measured with a Thermo Scientific melting point device. The mass spectra were recorded on an Agilent Technologies 6530 Accurate-Mass Q-TOF LC/MS. Solutions and UV-Vis spectra of some isoindole-1,3-dione $(\mathbf{5}, \mathbf{6}, \mathbf{7}, \mathbf{8}, 9$, and 10) compounds: The amounts of compounds 5, 6, 7, 8, 9, and $\mathbf{1 0}$ were arranged for $1 \mathrm{mM}$ with a AND-GR-200 Series Analytical Balance and these compounds were dissolved in $\mathrm{CH}_{2} \mathrm{Cl}_{2}$. Then, the UV-Vis spectra of compounds $\mathbf{5}, \mathbf{6 , 7 , 8 , 9}$, and $\mathbf{1 0}$ were recorded with a UV-1800 Shimadzu model spectrophotometer at room temperature.

\subsection{Synthetic procedures}

\subsection{General procedure for the preparation of (5) and (6) :}

Ethanolamine or 1-amino-2-propanol (1 mmol) was added to a magnetically stirred solution of 3a,4,7,7a-tetrahydroisobenzofuran-1,3-dione (4) $(1 \mathrm{mmol})$ in toluene $(10 \mathrm{~mL})$ and the mixture was refluxed for $36 \mathrm{~h}$. The solution was cooled, diluted with EtOAc $(20 \mathrm{~mL})$, washed with saturated aq. $\mathrm{NaHCO}_{3}(25 \mathrm{~mL})$, dried with $\mathrm{Na}_{2} \mathrm{SO}_{4}$, filtered, and concentrated to give a crude product. The crude product was separated by column chromatography [(CC; $\mathrm{SiO}_{2}(20 \mathrm{~g})$; EtOAc/n-hexane, 20:80)].

2.3. Synthesis of 2-(2-hydroxyethyl)-3a,4,7,7a-tetrahydro-1H-isoindole-1,3(2H)-dione (5) Crystalized from $\mathrm{CH}_{2} \mathrm{Cl}_{2} / n$-hexane. Yield: $95 \%$. Colorless crystals. M.p. $84^{\circ} \mathrm{C} .{ }^{1} \mathrm{H} \mathrm{NMR}\left(\delta, \mathrm{ppm}, 400 \mathrm{MHz}, \mathrm{CDCl}_{3}\right)$ : $5.90(m, 2 \mathrm{H}), 3.70(\mathrm{~m}, 3 \mathrm{H}), 3.12(\mathrm{~m}, 2 \mathrm{H}), 2.6(\mathrm{dm}, \mathrm{A}$ part of AB system $J=15.0 \mathrm{~Hz}, 2 \mathrm{H}), 2.36(\mathrm{~s}, \mathrm{OH})$, $2.24(d m, \mathrm{~B}$ part of $\mathrm{AB}$ system, $J=15.0 \mathrm{~Hz}, 2 \mathrm{H}) .{ }^{13} \mathrm{C} \mathrm{NMR}\left(\delta, \mathrm{ppm}, 100 \mathrm{MHz}, \mathrm{CDCl}_{3}\right): 180.79,127.73$, 60.74, 41.84, 39.12, 23.52. FT-IR $\left(\mathrm{cm}^{-1}\right): 3506.19 v(\mathrm{OH}), 2946.67 v(\mathrm{C}=\mathrm{C}-\mathrm{H}$ and $\mathrm{C}-\mathrm{C}-\mathrm{H}), 1766.78 v(\mathrm{C}=\mathrm{O}$ imide, asymmetric $), 1670.8 v(\mathrm{C}=\mathrm{O}$ imide, symmetric $), 1410.15 \mathrm{v}(\mathrm{C}=\mathrm{C})$.

HR-ESI-MS: $m / z$ 196.0994 $[M+\mathrm{H}]^{+}\left(\right.$calcd. $\left.196.0968[M+\mathrm{H}]^{+}\right)$ 
2.4. Synthesis of 2-(2-hydroxypropyl)-3a,4,7,7a-tetrahydro-1H-isoindole-1,3(2H)-dione (6) was synthesized as described in our previous study. ${ }^{13}$

\subsection{General procedure for the preparation of $(7)$ and $(8)$ :}

To a stirred solution of (5) or (6) $(1 \mathrm{mmol})$ in $10 \mathrm{~mL}$ of $\mathrm{CH}_{2} \mathrm{Cl}_{2}$ was added methanesulfonyl chloride $(2 \mathrm{mmol})$ at $0{ }^{\circ} \mathrm{C} . \mathrm{Et}_{3} \mathrm{~N}(2 \mathrm{mmol})$ was then added to the mixture The mixture was stirred for 24 h at $25{ }^{\circ} \mathrm{C}$ and extracted with $\mathrm{H}_{2} \mathrm{O}(3-4 \times 10 \mathrm{~mL})$, then dried with $\mathrm{Na}_{2} \mathrm{SO}_{4}$. The solution was evaporated under reduced pressure and gave a crude product. The crude product was separated by column chromatography [(CC; $\mathrm{SiO}_{2}(25 \mathrm{~g}) ; \mathrm{EtOAc/} n$-hexane, 20:80)].

2.6. Synthesis of 2-(1,3-dioxo-3a,4,7,7a-tetrahydro-1H-isoindol-2(3H)-yl) ethylmethanesulfonate (7) Crystallized from $\mathrm{CH}_{2} \mathrm{Cl}_{2} / n$-hexane. Yield: $98 \%$. Colorless crystals. M.p. $82{ }^{\circ} \mathrm{C}$. ${ }^{1} \mathrm{H}$ NMR $(\delta, \mathrm{ppm}, 400$ $\left.\mathrm{MHz}, \mathrm{CDCl}_{3}\right): 5.90(m, 2 \mathrm{H}), 4.36\left(\mathrm{~A}_{2}\right.$ part of $\left.\mathrm{A}_{2} \mathrm{~B}_{2}, 2 \mathrm{H}\right), 3.80\left(\mathrm{~B}_{2}\right.$ part of $\left.\mathrm{A}_{2} \mathrm{~B}_{2}, 2 \mathrm{H}\right), 3.13(\mathrm{~m}, 2 \mathrm{H}), 3.01$ $(m, 3 \mathrm{H}), 2.59(d m, \mathrm{~A}$ part of $\mathrm{AB}, J=15.3 \mathrm{~Hz}, 2 \mathrm{H}), 2.24(d m, \mathrm{~B}$ part of $\mathrm{AB}, J=15.3 \mathrm{~Hz}, 2 \mathrm{H}) .{ }^{13} \mathrm{C}$ NMR $\left(\delta, \mathrm{ppm}, 100 \mathrm{MHz}, \mathrm{CDCl}_{3}\right): 179.8,127.8,64.8,39.1,38.0,23.4$. FT-IR $\left(\mathrm{cm}^{-1}\right): 3025.0-2955.31 \mathrm{v}(\mathrm{C}=\mathrm{C}-\mathrm{H}$ and $\mathrm{C}-\mathrm{C}-\mathrm{H}), 1762.80 \mathrm{v}(\mathrm{C}=\mathrm{O}$ imide, asymmetric $), 1688.44 \mathrm{v}(\mathrm{C}=\mathrm{O}$ imide, symmetric $), 1414.05 \mathrm{v}(\mathrm{C}=\mathrm{C})$. HR-ESI-MS: $m / z 274.0772[M+\mathrm{H}]^{+}\left(\right.$calcd. $\left.274.0743[M+\mathrm{H}]^{+}\right)$

2.7. Synthesis of 1-(1,3-dioxo-3a,4,7,7a-tetrahydro-1H-isoindol-2(3H)-yl)propan-2-yl methanesulfonate $(8)$ was synthesized as described in our previous study. ${ }^{13}$

\subsection{General procedure for the preparation of (9) and (10) :}

To a stirred solution of (7) or $(\mathbf{8})(1 \mathrm{mmol})$ in $10 \mathrm{~mL}$ of DMF was added $\mathrm{NaN}_{3}(3 \mathrm{mmol})$ at room temperature. Ambient temperature was fixed at $70{ }^{\circ} \mathrm{C}$ and the mixture was stirred for $24 \mathrm{~h}$. The solution was evaporated under reduced pressure. To the mixture was added $10 \mathrm{~mL}$ of $\mathrm{CH}_{2} \mathrm{Cl}_{2}$ and extraction was performed with $\mathrm{H}_{2} \mathrm{O}(2 \times 10 \mathrm{~mL})$, followed by drying with $\mathrm{Na}_{2} \mathrm{SO}_{4}$ to give a crude product. The crude product was separated by column chromatography $\left[\left(\mathrm{CC} ; \mathrm{SiO}_{2}(20 \mathrm{~g}) ;\right.\right.$ EtOAc/n-hexane, 10:90)].

2.9. Synthesis of 2-(2-azidoethyl)-3a,4,7,7a-tetrahydro-1H-isoindole-1,3(2H)-dione (9) Yield: $87 \%$. Crystallized from $\mathrm{CH}_{2} \mathrm{Cl}_{2} / n$-hexane. Yellow crystals. M.p. $80^{\circ} \mathrm{C} .{ }^{1} \mathrm{H} \mathrm{NMR}\left(\delta, \mathrm{ppm}, 400 \mathrm{MHz}, \mathrm{CDCl}_{3}\right)$ : $5.90(m, 2 \mathrm{H}), 3.67\left(\mathrm{~A}_{2}\right.$ part of $\left.\mathrm{A}_{2} \mathrm{~B}_{2}, 2 \mathrm{H}\right), 3.45\left(\mathrm{~B}_{2}\right.$ part of $\left.\mathrm{A}_{2} \mathrm{~B}_{2}, 2 \mathrm{H}\right), 3.10(m, 2 \mathrm{H}), 2.62(d m, \mathrm{~A}$ part of $\mathrm{AB}, J=10.9 \mathrm{~Hz}, 2 \mathrm{H}), 2.24(d m, \mathrm{~B}$ part of AB system, $J=10.9 \mathrm{~Hz}, 2 \mathrm{H}) .{ }^{13} \mathrm{C} \mathrm{NMR}(\delta, \mathrm{ppm}, 100 \mathrm{MHz}$, $\left.\mathrm{CDCl}_{3}\right): 179.8,127.7,48.2,39.1,37.8,23.5$. FT-IR $\left(\mathrm{cm}^{-1}\right): 2953.57-2850.00 v(\mathrm{C}=\mathrm{C}-\mathrm{H}$ and $\mathrm{C}-\mathrm{C}-\mathrm{H})$, $2128.94 v(\mathrm{~N}=\mathrm{N}=\mathrm{N}), 2095.64 v(\mathrm{~N}=\mathrm{N}=\mathrm{N}), 1769.93 v(\mathrm{C}=\mathrm{O}$ imide, asymmetric $), 1691.46 \mathrm{v}(\mathrm{C}=\mathrm{O}$ imide, symmetric), $1426.54 \mathrm{v}(\mathrm{C}=\mathrm{C})$.

HR-ESI-MS: $m / z 221.1096[M+\mathrm{H}]^{+}\left(\right.$calcd. $\left.221.1039[M+\mathrm{H}]^{+}\right)$

2.10. Synthesis of 2-(2-azidopropyl)-3a,4,7,7a-tetrahydro-1H-isoindole-1,3(2H)-dione (10) Crystallized from $\mathrm{CH}_{2} \mathrm{Cl}_{2} / n$-hexane. Yield: $80 \%$. Light yellow crystals. M.p. $39-40{ }^{\circ} \mathrm{C} .{ }^{1} \mathrm{H} \mathrm{NMR}(\delta, \mathrm{ppm}, 400 \mathrm{MHz}$, $\left.\mathrm{CDCl}_{3}\right)$ : $5.90(\mathrm{~m}, 2 \mathrm{H}), 3.78(\mathrm{~m}, 1 \mathrm{H}), 3.57(d d, \mathrm{~A}$ part of AB system, $J=13.4,8.5 \mathrm{~Hz}, 1 \mathrm{H}), 3.4(d d$, B part of $\mathrm{AB}, J=13.4,5.0 \mathrm{~Hz}, 1 \mathrm{H}), 3.11(\mathrm{~m}, 2 \mathrm{H}), 2.62(\mathrm{dm}, \mathrm{A}$ part of AB system, $J=14.5 \mathrm{~Hz}, 2 \mathrm{H}), 2.24(d m$, B part of AB, $J=11.8 \mathrm{~Hz}, 2 \mathrm{H}), 1.24(d, J=6.6 \mathrm{~Hz}, 3 \mathrm{H}) .{ }^{13} \mathrm{C} \mathrm{NMR}\left(\delta, \mathrm{ppm}, 100 \mathrm{MHz}, \mathrm{CDCl}_{3}\right): 179.91$ (179.89), 127.80 (127.70), 54.93, 43.82, 39.08 (39.04), 23.57 (23.50), 17.18. FT-IR $\left(\mathrm{cm}^{-1}\right): 2970.68-$ $2800.00 v(\mathrm{C}=\mathrm{C}-\mathrm{H}$ and $\mathrm{C}-\mathrm{C}-\mathrm{H}), 2104.21 \mathrm{v}(\mathrm{N}=\mathrm{N}=\mathrm{N}), 1769.93 \mathrm{v}(\mathrm{C}=\mathrm{O}$ imide, asymmetric $), 1691.46 v(\mathrm{C}=\mathrm{O}$ imide, symmetric), $1429.18 \mathrm{v}(\mathrm{C}=\mathrm{C})$.

HR-ESI-MS: $m / z 235.1203[M+\mathrm{H}]^{+}\left(\right.$calcd. $\left.235.1195[M+\mathrm{H}]^{+}\right)$ 


\section{Result and Discussion}

\subsection{Synthesis}

Compounds 5-10 were synthesized starting from 3a,4,7,7a-tetrahydroisobenzofuran-1,3-dione (4). Compounds 4, 6, and $\mathbf{8}$ were synthesized as described in our previous studies ${ }^{13,21}$ and compound $\mathbf{5}$ is known in the literature. ${ }^{22}$ Compounds $\mathbf{7 , 9}$, and $\mathbf{1 0}$ are novel $N$-substituted isoindole-1,3-dione derivatives. The synthesis of all compounds was performed in three stages. For this purpose, first, the condensation of ethanolamine or 1-amino-2-propanol with compound $\mathbf{4}$ in toluene was carried out to synthesize imide compounds 5 and $\mathbf{6}$ as in our previous work (Scheme 1). ${ }^{13,21}$

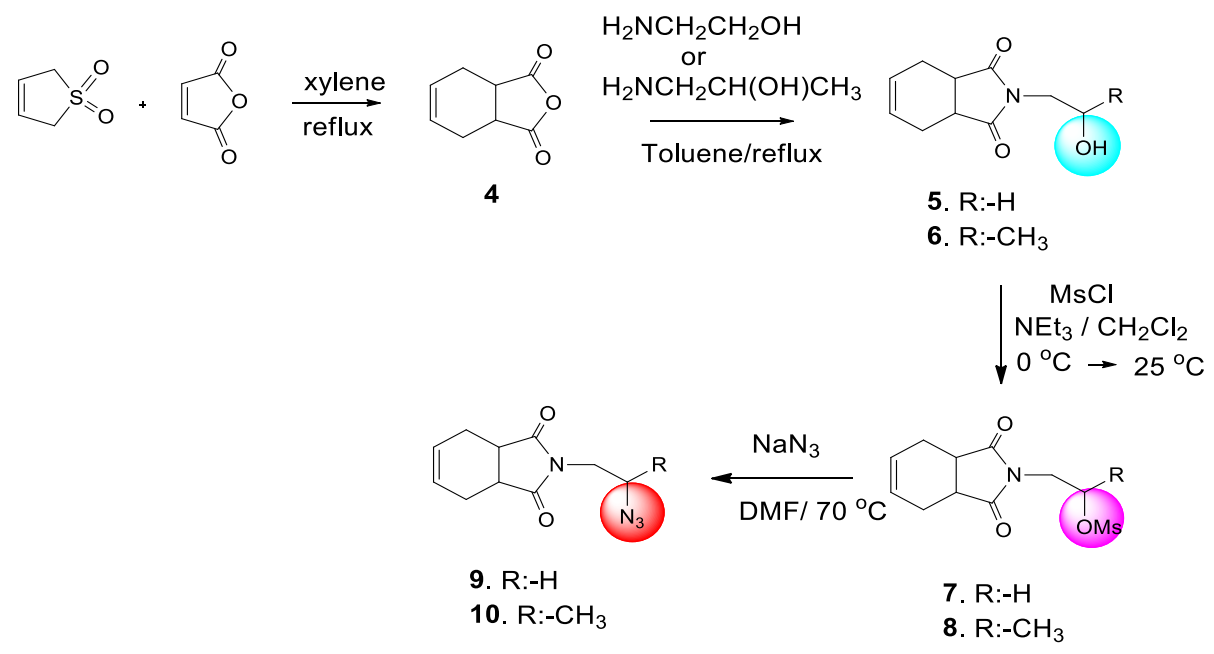

Scheme 1. The synthesis of imide compounds 5, 6, 7, 8, 9, and 10.

Imide compounds 5 and $\mathbf{6}$ were subjected to methanesulfonyl chloride for $24 \mathrm{~h}$ at temperatures from $0{ }^{\circ} \mathrm{C}$ to room temperature in dichloromethane to obtain compounds $\mathbf{7}$ and $\mathbf{8}$ (Scheme 1). Compounds $\mathbf{9}$ and $\mathbf{1 0}$ were synthesized via substitution of compounds $\mathbf{7}$ and $\mathbf{8}$ with $\mathrm{NaN}_{3}$ for $24 \mathrm{~h}$ at $70{ }^{\circ} \mathrm{C}$ in $\mathrm{N}, \mathrm{N}$ dimethylformamide (DMF). "-OMs" group was replaced with azide "-N $\mathrm{N}_{3}$ " group having delocalized $\pi$ electrons. The structures of compounds 9 and 10 were assigned by the ${ }^{1} \mathrm{H}$ NMR, ${ }^{13} \mathrm{C}$ NMR, and FT-IR spectra.

\subsection{Optical properties}

The UV-spectrum of a material can be analyzed with absorbance $(A b s)$, transmittance $(T)$, and reflectance $(R)$ measurements. Figure $2 \mathrm{a}$ indicates the absorbance curves versus the wavelength $(\lambda)$ of compounds 5, 6, 7, 8, 9, and 10. As seen in Figure 2a, compounds 5, 6, 7, 8, 9, and 10 display maximum absorbance peaks at 229,231,230,230,229, and $229 \mathrm{~nm}$, which correspond to the near ultraviolet (NUV) region. ${ }^{23,24}$ As seen in Figure 2a, the absorbance spectra of compounds 5, 6, 7, 8, 9, and 10 are dominant in the NUV region, while the absorbance spectra of compounds $\mathbf{5 , 6 , 7 , 8 , 9}$, and 10 are almost constant in the visible $(\mathrm{V})$ region. It is seen that there is a difference among the absorbance spectra of compounds $\mathbf{5}, \mathbf{6}, \mathbf{7}, \mathbf{8}, 9$, and 10, but the wavelengths of their maximum absorbance peaks are almost unchanged. 


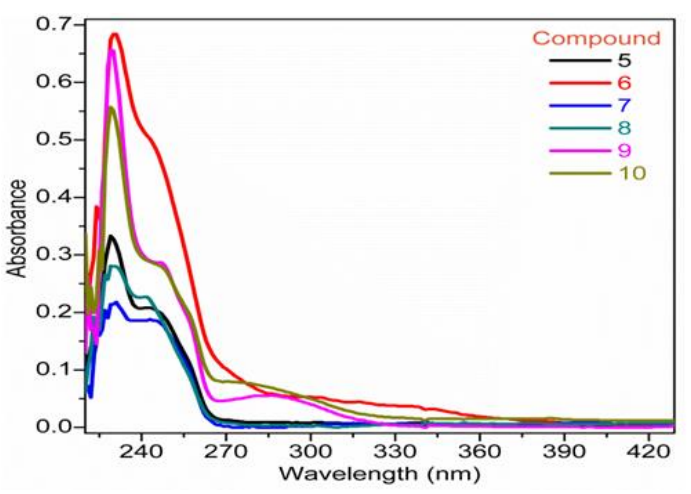

(a)

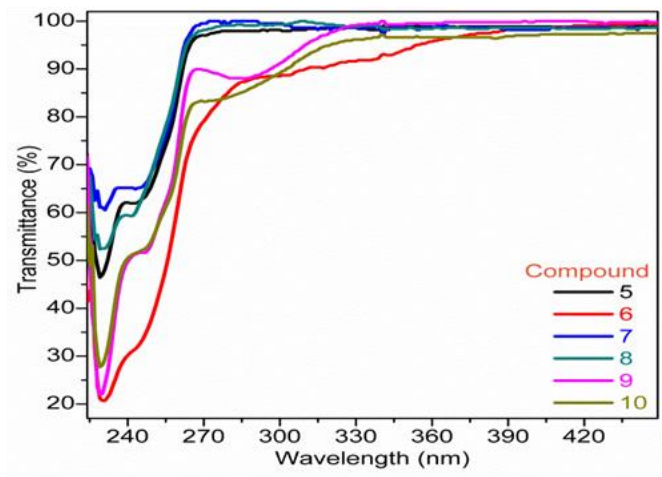

(b)

Figure 2. The (a) absorbance and (b) transmittance curves vs. wavelength $(\lambda)$ of compounds $5,6,7,8$, $\mathbf{9}$, and $\mathbf{1 0 .}$

Figure $2 \mathrm{~b}$ indicates the transmittance curves versus $\lambda$ of compounds $\mathbf{5 , 6 , 7 , 8 , 9}$, and $\mathbf{1 0}$. These compounds have very high permeability. The transmittance spectra of compounds $\mathbf{5 , 6 , 7 , 8 , 9}$, and 10 are dominant in $\mathrm{V}$ region.

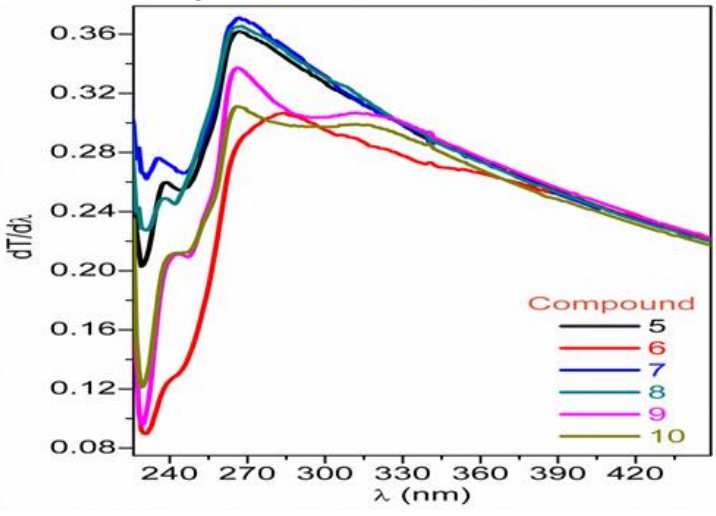

(a)

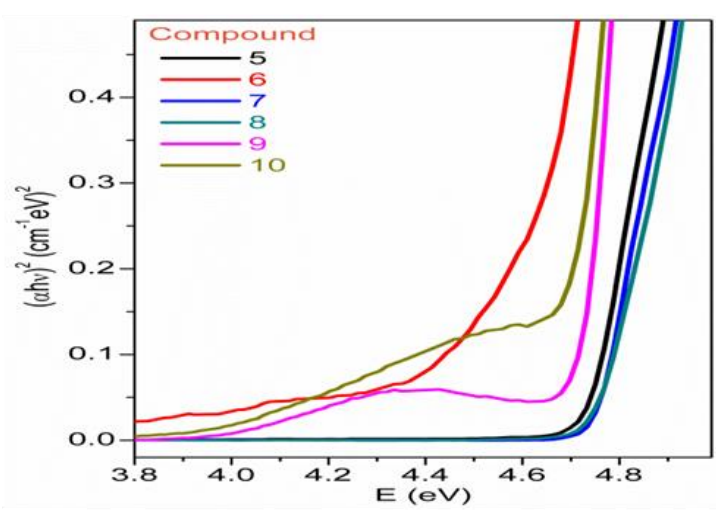

(b)

Figure 3. The (a) $d T / d \lambda$ curves versus $\lambda$ and (b) $(\alpha \mathrm{hv})^{2}$ curves versus photon energy $(E)$ of compounds $5,6,7,8,9$, and 10 .

We plotted the $d T / d \lambda$ curves versus $\lambda$ of compounds $5,6,7, \mathbf{8}, 9$, and 10 as seen in Figure $3 a$, to obtain the absorbance band edge $\left(E_{A b s-b e}\right)$, which gives useful features for optical properties. The $E_{A b s-b e}$ values of these compounds were calculated from the maximum peaks of the curves and are given in Table 1. As seen there, the $E_{A b s-b e}$ of these compounds varies from 4.366 to $4.662 \mathrm{eV}$.

Table 1. The absorbance band edge (EAbs-be) and optical band gap $(E g)$ of compounds $5,6,7,8,9$, and $\mathbf{1 0}$.

\begin{tabular}{lll}
\hline Compounds & $\boldsymbol{E}_{\text {Abs-be }}(\boldsymbol{e V})$ & $\boldsymbol{E}_{\boldsymbol{g}}(\boldsymbol{e V})$ \\
\hline $\mathbf{5}$ & 4.644 & 4.672 \\
$\mathbf{6}$ & 4.366 & 4.236 \\
$\mathbf{7}$ & 4.644 & 4.700 \\
$\mathbf{8}$ & 4.627 & 4.671 \\
$\mathbf{9}$ & 4.662 & 4.627 \\
$\mathbf{1 0}$ & 4.662 & 4.532 \\
\hline
\end{tabular}


Table 2. The refractive index parameters obtained from the Moss, Herve-Vandamme, Reddy and KumarSingh relations of compounds $5,6,7,8,9$, and 10 .

\begin{tabular}{|c|c|c|c|c|}
\hline \multirow[b]{2}{*}{ Compounds } & \multicolumn{2}{|c|}{$\begin{array}{l}\text { Refractive index }(n) \\
\text { values }\end{array}$} & \multirow[b]{2}{*}{ Reddy } & \multirow[b]{2}{*}{$\begin{array}{l}\text { Kumar- } \\
\text { Singh }\end{array}$} \\
\hline & Moss & $\begin{array}{c}\text { Herve- } \\
\text { Vandamme }\end{array}$ & & \\
\hline 5 & 2.124 & 1.947 & 2.445 & 2.048 \\
\hline 6 & 2.176 & 2.029 & 2.512 & 2.114 \\
\hline 7 & 2.120 & 1.942 & 2.441 & 2.044 \\
\hline 8 & 2.124 & 1.947 & 2.446 & 2.049 \\
\hline 9 & 2.129 & 1.955 & 2.452 & 2.049 \\
\hline 10 & 2.140 & 1.972 & 2.466 & 2.069 \\
\hline
\end{tabular}

The optical band gap $\left(E_{g}\right)$ determines the band structure and type of conductivity of the material, and is one of the most important parameters in the investigation of optical properties. To obtain the $E_{g}$ values of compounds $\mathbf{5}, \mathbf{6}, \mathbf{7}, \mathbf{8}, \mathbf{9}$, and 10, we used the Tauc model ${ }^{25}$ and benefited from its applications. ${ }^{23,24,26}$ For this, we plotted the $(a h v)^{2}$ curves versus photon energy $(E)$ ( $\alpha$ is the absorption coefficient) of these compounds as seen in Figure 3b. As shown in Table 1, the $E_{g}$ value $(4.236 \mathrm{eV})$ of compound 6 is the lowest, while the $E_{g}$ value $(4.700 \mathrm{eV})$ of compound 7 is the highest.

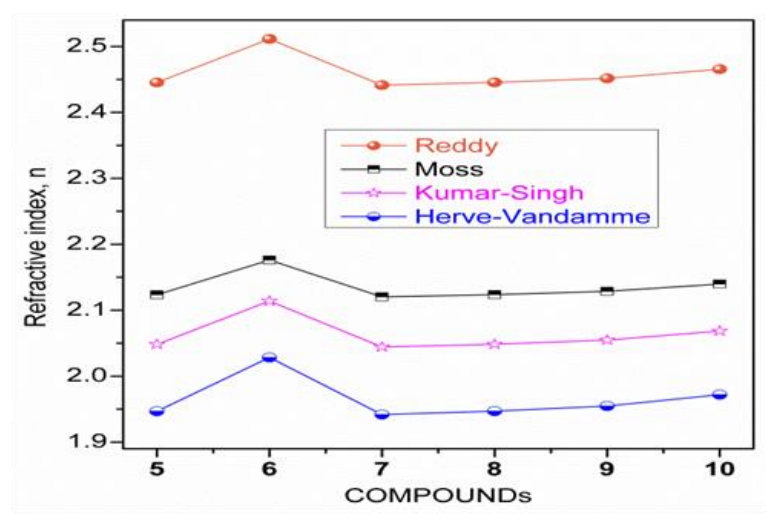

Figure 4. The refractive index curves for different compounds and relations.

The refractive index $(n)$ has a very important place among the parameters of the optical properties and can be obtained from many different techniques and equations. The refractive indices of compounds $\mathbf{5}, \mathbf{6}, \mathbf{7}, \mathbf{8}, \mathbf{9}$, and 10 were obtained from various relations, ${ }^{27,28}$ such as the Herve-Vandamme, KumarSingh, Moss, and Reddy relations. The obtained refractive indices of these compounds are given in Table 2. Figure 4 indicates the $n$ curves for different compounds and relations. It is seen that the refractive index of these compounds varies from 1.942 to 2.512 .

As a conclusion, this study was carried out in two stages. First, some isoindole-1,3-dione compounds $(\mathbf{5}, \mathbf{6}, \mathbf{7}, \mathbf{8}, 9$, and 10) were synthesized starting from 3a,4,7,7a-tetrahydroisobenzofuran-1,3dione (4) in three stages. All compounds were synthesized by simple but effective methods. These compounds have "-OH, -OMs, and $-\mathrm{N}_{3}$ " functional groups and are very important as starting materials for substitution reactions and click chemistry. Secondly, the optical properties of these compounds were investigated by UV-Vis absorption spectroscopy and their optical parameters were compared with each other. The UV-Vis spectra of these compounds were recorded in $\mathrm{CH}_{2} \mathrm{Cl}_{2}$. The $A b s, T, E_{A b s-b e}, E_{g}$, and (n) of these compounds were calculated. The $A b s$ curves of these compounds are dominant in the NUV region and the $A b s$ peaks vary from 229 to $231 \mathrm{~nm}$. The $T$ curves of these compounds are dominant in the V region with high permeability. Therefore, these compounds can be seen as advantageous for technologies 
and applications that require high permeability. The $E_{\text {Abs-be }}$ of these compounds varies from 4.366 to 4.662 $\mathrm{eV}$, indicating insulator materials with very poor conductivity. The $E_{g}$ of compounds $5,6,7, \mathbf{8 , 9}$, and 10 exhibit insulator/dielectric behavior and these compounds can be used as the oxide layer in metal oxide semiconductors and as insulating layers in transistors. The refractive indices of these compounds were calculated. As seen in Figure 4, the highest refractive indices are obtained from the Reddy relation for compound 6, while the lowest refractive indices are obtained from the Herve-Vandamme relation for compound 7. These results showed that the different functional groups ("- $\mathrm{OH},-\mathrm{OMs}$, and $-\mathrm{N}_{3}$ ") in the molecules (5-10) do not significantly change their optical properties.

\section{Acknowledgements}

The authors are grateful to Mus Alparslan University for financial support (Grant No. BAP-18TBMY-4901-01) and to Atatürk University for ${ }^{1} \mathrm{H}$ NMR and ${ }^{13} \mathrm{C}$ NMR spectra. This study is a part of $\mathrm{PhD}$ thesis of Serap Kizilkaya.

\section{Supporting Information}

Supporting information accompanies this paper on http://www.acgpubs.org/journal/organic$\underline{\text { communications }}$

\section{ORCID}

Ayse Tan: 0000-0003-2692-7923

Serap Kizilkaya: 0000-0002-1398-3881

Bayram Gunduz: 0000-0002-1447-7534

Yunus Kara: 0000-0001-7552-9425

\section{References}

[1] Prado, S.R.; Cechinel-Filho, V.; Campos-Buzzi, F.; Corrèa, R.; Cadena, S.M.; De Oliveira, M.B. Biological evaluation of some selected cyclic imides: mitochondrial effects and in vitro cytotoxicity. Z. Naturforsch. C 2004, 59, 663-672.

[2] Sabastiyan, A.; Suvaikin, M.Y. Synthesis, characterization and antimicrobial activity of 2(dimethylaminomethyl) isoindoline-1,3-dione and its cobalt(II) and nickel(II) complexes. Adv. in Appl. Sci. Res. 2012, 3, 45-50.

[3] Hassazadeh, F.; Rabbani, M.; Khodarahmi, G.A.; Fasihi, A.; Hakimelahi, G.H.; Mohajeri, M. Synthesis of phthalimide derivatives and evaluation of their anxiolytic activity. Res. Pharm. Sci. 2007, 2, 35-41.

[4] Lima, L.M.; Castro, P.; Machado, A.L.; Fraga, C.A.; Lugnier, C.; De Moraes, V.L.; Barreiro, E.J. Synthesis and anti-inflammatory activity of phthalimide derivatives, designed as new thalidomide analogues. Bioorg. Med. Chem. 2002, 10, 3067-3073.

[5] AbdeI-Hafez, A.A. Synthesis and anticonvulsant evaluation of N-substituted isoindolinedione derivatives. Arch. Pharm. Res. 2004, 27,495-501.

[6] Kok S.H.L. et al Synthesis and anti-cancer activity of benzothiazole containing Phthalimide on human carcinoma cell lines. Bioorg. Med. Chem. 2008, 16, 3626-3631.

[7] Sami, S.M.; Dorr, R.T.; Alberts, D.S.; Solyom, A.M.; Remers, W.A. Analogues of amonafide and azonafide with novel ring systems. J. Med. Chem. 2000, 43, 3067-3073.

[8] Wang, J.J.; Liu, T.Y.; Yin, P.H.; Wu, C.W.; Chern, Y.T.; Chi, C.W. Adamantyl maleimide induced changes in adhesion molecules and ROS are involved in apoptosis of human gastric cancer cells. Anticancer Res. 2000, 20, 3067-3073.

[9] Li, M.; Sun, W.; Yang, Y.; Xu, B.; Yi, W.; Ma, Y.; Li, Z.; Cui, J. In vitro anticancer property of a novel thalidomide analogue through inhibition of NF- $\kappa B$ activation in HL-60 cells. Acta Pharm. Sin. 2009, 30, 134140.

[10] Ching, L.M.; Browne, W.L.; Tchernegovski, R.; Gregory, T.; Baguley, B.C.; Palmer, B.D. Interaction of thalidomide, phthalimide analogues of thalidomide and pentoxifylline with the anti-tumour agent 5, 6dimethylxanthenone-4-acetic acid: concomitant reduction of serum tumour necrosis factor-alpha and enhancement of anti- tumour activity. British J. Can. 1998, 78, 336-343. 
[11] Singh, J.; Singha, T.; Naskar, A.; Kundu, M.; Harwansh, R.K.; Mondal, A.; Ghosh, T.; Maity, T.K. Synthesis and anti-proliferative activity of some isoindoline-1, 3-dione derivatives against ehrlich's ascites carcinoma bearing mice model. Pharmacologyonline 2011, 2, 976-987.

[12] Kose, A.; Bal, Y.; Kishali, N.H.; Sanli-Mohamed, G.; Kara, Y. Synthesis and anticancer activity evaluation of new isoindole analogues. Med. Chem. Res. 2017, 26 (4), 779-786.

[13] Tan, A.; Bozkurt, E.; Kara, Y. Investigation of solvent effects on photophysical properties of new aminophthalimide derivatives-based on methanesulfonate. J. Fluoresc. 2017, 27, 981-992.

[14] Tamer, O.; Bhatti, M.H.; Yunus, U.; Nadeem, M.; Avc1, D.; Atalay, Y.; Yaqub, A.; Quershi, R. Structureproperty relationship of 3-(N-phthalimidomethyl)-4-amino-1,2,4-triazole-5-thione: A structural, spectroscopic and DFT Study. J. Mol. Struct. 2017, 1133, 329-337.

[15] Ledoux, I. New advances in molecular engineering for quadratic nonlinear optics. Synth. Metals 1993, 54, 123-137.

[16] Yuan, D.R.; Xu, D.; Zhang, N.; Liu, M.G.; Jiang, M.H. Organic nonlinear optical crystal MHBA for compact blue-violet laser. Chin. Phys. Lett. 1996, 13, 841-843.

[17] Pecaut, J.; Bagieu-Beucher, M. 2-Amino-5-nitropyridinium monohydrogenphosphite. Acta Cryst. C 1993, 49, 834-837.

[18] Boobalan, M.S.; Amaladasan, M.; Ramalingam, S.; Tamilvendan, D.; Prabhu, G.V.; Bououdina, M. First principles and DFT supported investigations on vibrational spectra and electronic structure of 2((phenylamino) methyl) isoindoline-1, 3-dioneeAn antioxidant active Mannich base. Spectro. Acta Part A. 2015, 137, 962-978.

[19] Ozdemir, N.; Dinçer, M.; Çukuroval1, A. An experimental and theoretical approach to the molecular structure of 2-\{4-[3-(2, 5-dimethylphenyl)-3-methylcyclobutyl] thiazol-2-yl\} isoindoline-1, 3-dione. J. Mol. Mod. 2010, 16, 291-302.

[20] Kataria, S.; Rhyman, L.; Ramasami, P.; Sekar, N. Comprehensive DFT and TD-DFT studies on the photophysical properties of 5,6-dichloro-1,3-bis(2-pyridylimino)-4,7-dihydroxyisoindole: a new class of ESIPT fluorophore. J. Fluoresc. 2016, 26, 1805-1812.

[21] Tan, A.; Koc, B.; Sahin, E.; Kishali, N.H.; Kara, Y. Synthesis of New Cantharimide Analogues Derived from 3-Sulfolene. Synthesis 2011, 7, 1079-1084.

[22] Ranise, A.; Spallarossa, A.; Cesarini, S.; Bondavalli, F.; Schenone, S.; Bruno, O.; Menozzi, G.; Fossa, P.; Mosti, L.; La Colla, M.; Sanna, G.; Murreddu, M.; Collu, G.; Busonera, B.; Marongiu, M.E.; Pani, A.; La Colla, P.; Loddo, R. Structure-Based Design, Parallel Synthesis, 'Structure-Activity Relationship, and Molecular Modeling Studies of Thiocarbamates. New Potent Non-Nucleoside HIV-1 Reverse Transcriptase Inhibitor Isosteres of Phenethylthiazolylthiourea Derivatives. J. Med. Chem. 2005, 48, 3858-3873 and references therein.

[23] Gunduz, B. Controlling of spectral and optical parameters of the F8T2 liquid-crystalline polymer (LCP) by molarity for optoelectronic devices. Optik 2015, 126, 4566-4573.

[24] Gunduz, B. Investigation of the spectral, optical and surface morphology properties of the N,N-Dipentyl3,4,9,10-perylenedicarboximide small molecule for optoelectronic applications. Polym. Adv. Techn. 2016, 27, 144-155.

[25] Tauc, J.; Menth, A. States in the gap. J. Non-Cryst. Solids 1972, 8-10, 569-585.

[26] Gunduz, B. Effects of molarity and solvents on the optical properties of the solutions of tris[4-(5dicyanomethylidenemethyl-2-thienyl)phenyl]amine (TDCV-TPA) and structural properties of its film. Opt. Mater. 2013, 36(2), 425-436.

[27] Tripathy, S.K. Refractive indices of semiconductors from energy gaps. Opt. Mater. 2015, 46, 240-246.

[28] Kurban, M.; Gunduz, B. Physical and optical properties of DCJTB dye for OLED display applications: Experimental and theoretical Investigation. J. Mol. Struct. 2017, 1137, 403-411.

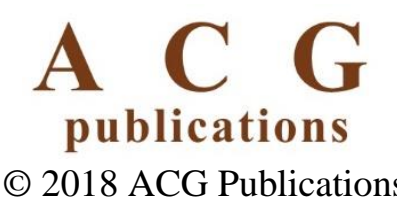

